\title{
An Analysis of Teacher's Techniques in Teaching English Vocabulary to Young Learners in English Courses in Lubuk Basung
}

\author{
Mici Amalisa ${ }^{*}$ and Yenni Rozimela ${ }^{2}$ \\ ${ }^{1}$ English Department, FBS Universitas Negeri Padang, Padang, Sumatra Barat 25131, Indonesia \\ ${ }^{2}$ English Department, FBS Universitas Negeri Padang, Padang, Sumatra Barat 25131, Indonesia \\ "Corresponding author. Email: mici4amalisa@gmail.com
}

\begin{abstract}
This research aims to describe the teaching techniques used by the teachers in teaching English vocabulary to young learners. The type of this research was descriptive research. The participants of this research were six English teachers who teach at 3rd grade to 6th grade of Elementary School and 13 students of Elementary School level at three English courses in Lubuk Basung. The research data was collected through observation and interview. Observation and interviews were conducted to each teacher and interviews were also carried out to some of the students selected by purposive sampling. Then, the data were analyzed by using a qualitative approach. The findings of this research showed that there was eleven technique used by English teachers in teaching vocabulary, they are; showing actual objects, using demonstrations, showing pictures, drawing, associated vocabulary, translation, role play, reading the word, using a dictionary, contrast, eliciting, Mime-Expression and Gesture. Those techniques are used by teachers to increase students' vocabulary. By using those techniques, the teacher can teach the material clearly to the student. Several students are motivated in learning vocabulary because of their own willingness, such as review the lessons and memorize the vocabulary.
\end{abstract}

Keywords: Teacher's techniques, teaching English vocabulary, young learners, English courses

\section{INTRODUCTION}

Vocabulary is the primary subject for young learners in learning English. Most of young learners' lessons in English learning program will lead them to the vocabulary mastery. Teaching vocabulary is the most significant aspect in language teaching because words are the foundation of a language [1]. Therefore, teaching this subject effectively to young learners should be a concern for teachers. However, teaching vocabulary for young learners is not a typical language teaching. There are numerous points that should be taken into consideration.

The materials, the teaching method, strategy, and techniques are the major points in teaching vocabulary for young learners. But, teachers' techniques are the most crucial among those points. The young learner's different way of learning is the reason of this argument.

There are several characteristic of young learners; they have short attention span, they are imaginative, enjoy imitating and learning through playing [2]. Thus, teaching this group of learners should be more specific than adult. The teachers should prepare various appropriate and interesting techniques to keep the learners enthusiast in learning.
The techniques should be prepare and applied effectively, thus the learners could enjoy their learning and master the vocabulary given. It is because good teachers are them who know and apply the techniques effectively and appropriately, and the good techniques are useless without this kind of good teachers [3].

This requirement of teaching for young learners has become problems for teachers. Gaining both learners; interest and achievement are challenging for several teachers. Providing and applying the best techniques for teaching vocabulary to young learners are the most principal requirement for teaching young learners in every English learning program.

Regarding the English learning program for young learners, there is a common opinion that the learners will have better English proficiency if they are sent to English courses. Exploring the teaching and learning process, especially the teachers' techniques in English courses has become writer interest. Therefore, the researcher interest in research teaching vocabulary entitled "An analysis of teachers' techniques in teaching English vocabulary to young learners at English course in Lubuk Basung".

In the writer pre-observation, there were several strategies used by the teachers in the courses in teaching 
vocabulary such as memorize, translate, sing a song, and play a game. However, these techniques are still limited if compared to the techniques explained by experts in language teaching. More observation is needed to find out the way the teachers teach vocabulary to the students. It was also known that the students who join those courses have better English than the students who only learn English from school. It can prove from the students' English scores. The real techniques and their implementation at these English courses are needed to explore because the teachers should have different techniques to teach their students.

\section{LITERATURE REVIEW}

Regarding the teaching vocabulary for young learners, there are two major points to discuss; principal and techniques for teaching vocabulary for young learners.

\section{1. The Principal of Teaching for Young Learners}

Young learners are the learners who are not adult yet, they are included in elementary school. Knowing the age and level of the learners is crucial for the teacher to know and understand how and what to teach. Learners have different needs and competences depend on their age. Thus, the most principal factor to consider in teaching young learners is knowing their characteristic and the appropriate techniques to use. There are several general characteristics of young learners; they know situation faster than the language, their understanding comes through touching, seeing, and hearing, very logical, they have short attention and concentration span, they have difficulty in differentiating fact and fiction, they cannot determine what to learn by themselves, they learn through playing, and when they are interested, they are enthusiastic and positive, and they have their own mind about the world [4].

To consider those characteristics, the teachers should understand the difference in the way of teaching young learners and adults. Their linguistic, psychological, and social development are different. Thus, the teachers have to consider how they think about the language and the teaching activities they use.

In learning vocabulary, the characters of young learners are: if they do not understand, they still respond to the meaning of words, they often study indirectly, learn everything around them, the interest and enthusiasm about their world, their knowledge comes from what they hear, see, and interact directly every day [5].

The teachers should remember some basic principles in teaching vocabulary to young students. First, the teacher should engage the student's interest and think while learning because young learners desire about learning new words. Young learners are able to understand the concept of words well than grammar. Without directly being taught, they will understand the meaning [6].

Second, teachers must introduce vocabularies that they can see, touch, play, and interact with because young students are not prepared to learn abstract words beyond their imagination [7].

Third, the teacher needs to teach limited vocabularies in one meeting because children have limited attention span. Then, it can revisit in the next meeting to help them memorize the words that have learned [8].

Fourth, in teaching vocabulary to young learners, the teacher should engage the students to know not only its word but also other related words such as its meaning, use, and form [9].

Last, the teacher should teach the learners in combination rather than in isolation because young learners are not able to analyse the composition of the language system, such as grammar [10].

\section{2 Techniques for Teaching Vocabulary}

Teachers' knowledge about age and characteristics of learners can also help them succeed in apply teaching technique in the classroom. Teachers are expected to be able to find various and interesting techniques because children are easy to get bored. Techniques in teaching and materials in learning are given to students must be interesting and enjoyable so that keep their attention in learning.

The technique in teaching is a collection way used in the teaching-learning process. In this study, the research can share some techniques for teaching vocabulary. There are many techniques to innovative the meaning of new words [11].

The first is showing actual objects and showing models. It is a very helpful technique to teach vocabulary to beginners. By showing the actual objects can teach many things of vocabulary and sense to the learner. In showing meanings, real objects or models are very effective but in the handling of real objects.

The second, using demonstrations and pictures, teacher can show some words or the picture to students. It makes the teaching learner-centered. A teacher can practice suitable for words or vocabulary and ask the learners to imitate. This method is easy and can be practiced.

The third is drawing. For students, drawing can be a interesting way to teach vocabulary. Drawing is an simple technique to introducing vocabulary to young learners. The meaning of things, actions, qualities, and relations can be explained by drawing. 
The next is associated vocabulary. It is easy to teach these entire words together if one topic consists of several words. For example, it is simple to teach words like apple, orange, watermelon, together in the context of fruit than these words in isolation.

The next is the Dictionary. A teacher needs to encourage learners to search for words in dictionaries. The significant and effective component of understanding a word is by exploring dictionary entries

The next is the game. It increases the students' memory of words. It influences learning because one of the young learner's characteristics is easy to lose attention. Thus the teacher should provide an enjoyable and fun game in learning vocabulary.

The last technique to discuss in this study is Mime, Expressions, and Gestures. "Mime or gesture is useful if it emphasizes the importance of gestures and facial expression in communication. Many words can be introduced through mime, expressions, and gestures. For example, adjectives: "happy"," sad"; mime and taking a hat off your head to teach hat, and so on" [12].

There are numerous other techniques proposed by experts that can implement in teaching vocabulary for young learners. They should be applied by considering the principals of teaching vocabulary to young students.

\section{METHOD}

This study was conducted at three English courses in Lubuk Basung. In order to collect the data regarding the teachers techniques in teaching vocabulary for young learners at three English courses in Lubuk Basung, the writer conducted observation to six English teachers' at this three different English courses. The teachers observed every teacher's acts and activities that reflect their real techniques in teaching. The observation was followed by interview to confirm the data taken from the observation. The interview was also included several questions related to the teaching vocabulary techniques applied by the teachers at those three English courses. Observation and interviews were conducted to each teacher and interviews were also carried out to some of the students. Finally the writer achieved the data on the real techniques applied by the teachers in teaching vocabulary for young learners in these three English courses.

\section{FINDING AND DISCUSSION}

After collecting and analyzing the data from observation and interview, the write found out that there are various techniques implemented by the teachers in teaching vocabulary for young students at three English courses in Lubuk Basung. they are; showing actual objects, using demonstrations, showing pictures, drawing, associated vocabulary, translation, role play, reading the word, using dictionary, contrast, eliciting, Mime-Expression and Gesture.

These techniques were found out as the common techniques applied by the teachers at those three English courses. In applying these techniques, the teachers were found out to use more than one technique in a single meeting. For example, combining showing picture or real object with translation was the most common techniques found in the observation and interview. Among the techniques that found out in the observation and interview, using the real object, demonstration, and picture were the most dominant techniques used by the teachers.

In using the real object during the vocabulary teaching, the teacher showed the learners the real object in the classroom, for example; the things in classroom; desk, whiteboard, the part of body and other objects around the classroom [13]. In applying this techniques, it was found that the teacher combining this technique with read aloud and repetition. The teachers seemed interactively applied these techniques to catch the learners interest and comprehension in vocabulary given. The real object is considered as the most appropriate techniques to apply for young learners because it will make them memorize the words better.

The second major technique applied by the teachers was demonstration. It was observed that one of the topics taught by the teacher by using this technique was in verb. The teachers commonly demonstrate the verb, e.g. jump, walk, run etc. by demonstrating those word by directly. This techniques usually followed by asking the students to guess the word meaning demonstrated by the teachers. Demonstrating is an appropriate technique for teaching vocabulary to young learner. It is not enough for young learners to understand words by explanation only. They need to acquire words by directly seeing and hearing [14].

The third technique found out commonly used by the teachers was using picture. One of the topics observed were taught by using this technique was transportation. The teachers provided the students several pictures related to transportation; airplane, car, train, etc. the pictures were also completed by simple questions. The teacher also asked the student to repeat the pronunciation of the words. Using picture is always helpful because it allows the learners to see the shape of the object directly through the pictures rather than asking them to imagine the object only [15].

The result of observation and interview also revealed that the teachers at those three English courses were actually considered the principals of teaching for young learners thus they provide interested techniques in teaching although the learners' vocabulary mastery is 
the most importance goal for the teachers and their English courses.

\section{CONCLUSION}

Based on the result of observation and interview regarding the teachers techniques in teaching vocabulary for young learners, the teachers at three English courses in Lubuk Basung used various and specific teaching techniques interactively in teaching vocabulary to Elementary level students in order to make the young learners interest in learning vocabulary and to achieve the students mastery in vocabulary.

\section{REFERENCES}

[1] S. Thornburry, how to teach vocabulary. England: Pearson Education Limited, 2002.

[2] W. A. Scoot and L. H. Ytreberg, Teaching English To Children. London: Longman, 2001.

[3] H. R. Lang and D. N. Evans, Models, Strategies, and Methods for Effective Teaching. England: Pearson, 2006.

[4] M. Slattery and J. Willis, English for Primary Teachers - A handbook of activities \& classroom language. Oxford University Press, 2001.

[5] B. Brenddon, "Characteristic of Young Learners," 2012. [Online]. Available: http://brendabrendon.blogspot.com/2012/12/charac teristic-of-young-learners.html. [Accessed Dec. 20, 2020]

[6] A. Pinter, Teaching Young Language Learners. Oxford University Press, 2006.

[7] H. D. Brown, Teaching by Principle: An Interactive Approach to Pedagogy (2nd Ed),. Longman, 2001.

[8] I. S. P. Nation, "How large a vocabulary is needed for reading and listening?," Can. Mod. Lang. Rev., vol. 63, no. 1, 2006, doi: 10.3138/cmlr.63.1.59.

[9] L. Cameron, Teaching Languages to Young Learners. Cambridge University Press, 2001.

[10] A. Pinter, Teaching Young Language Learners. Oxford University Press, 2007.

[11] V. P. Takač, Vocabulary Learning Strategies and Foreign Language Acquisition. Multilingual Matters, 2008.

[12] F. Klippel, Keep Talking: Communicative Fluency Activities for Language Teaching. Cambridge University Press, 2012.

[13] J. Harmer, The Practice of English Language Teaching, Third. London: Longman, 2002.

[14] M. ALQAHTANI, "The importance of vocabulary in language learning and how to be taught," Int. J. Teach. Educ., vol. III, no. 3, 2015, doi: 10.20472/te.2015.3.3.002.

[15] A. Wright, Picture For Language Learning.
Cambridge University Press, 2007. 